\title{
Maden Atık Çamurlarının Denizaltı Depolama Yöntemi ile Bertarafı
}

\author{
Naim Sezgin ${ }^{1, *}$ \\ ${ }^{1}$ İstanbul Üniversitesi-Cerrahpaşa, Mühendislik Fakültesi, Çevre Mühendisliği Bölümü, 34320, İstanbul.

\section{Özet}

Madencilik endüstrisi modern toplumun gelișmesinde rol oynayan en önemli endüstriyel faaliyetlerinden biri olmakla birlikte dünyanın en büyük atık üreten endüstrisidir. Gelişen teknoloji ve endüstriyel faaliyetlerin ihtiyact olan hammaddelerin madencilik faaliyetleri ile doğal kaynaklardan elde edilmesi, biyolojik çeșitlilï̆in yok edilmesine ve çevre kirliliği sorunlarına neden olabilmektedir. Madencilik faaliyetlerinden vazgeçilmesi mümkün olmadı̆̆ına göre, madenlerin çıkartılmasında kamu yararının yanında doğal kaynakların korunması ve çevre kirliliği oluşturmaması konusunda da daha duyarlı olunmalı ve uygun bertaraf yöntemleri için çeşitli mühendislik tekniklerinin uygulanması hedeflenmelidir. Madencilik faaliyetleri sonucu oluşan atıklardan olan çamur genel olarak arazilerde (atık barajlarında veya atık döküm sahalarında) depolanarak bertaraf edilmektedir. Bu depolama alanlarında ise asit maden drenajı (sülfit oksidasyonundan dolayl), geoteknik stabilite ve diğer bazı sebeplerden dolayı çevresel sorunlar meydana gelebilmektedir. Yerüstü atık barajları depolama alanlarında oluşan olumsuz nedenlerden dolayı maden atığı çamurların sucul alıcı ortamlarda bertarafi, özellikle sabit indirgeme koşulları altında ve sülfit minerallerinin jeokimyasal olarak istikrarlı olduğu derin deniz altlarında bertarafi bir seçenek olarak görülebilir. Bu çalıșmada, maden atıklarının ve maden cevheri zenginleştirme atıklarından olan sulu çamurun (maden atık çamurunun) genel bertaraf yöntemleri, özellikle denizaltına deşarj ve denizaltında depolama yöntemi incelenmiştir. Bu yöntemin olası olumlu/olumsuz çevresel etkileri tartışılmıştır. Türkiye'de bulunan maden atı̆̆ çamuru derin denizaltı depolama (Karadeniz için) tesisi ve bu deşarjın (yöntemin) etkilerini belirlemek için yapılan deneysel çalışmalar değerlendirilmiştir. Bu kapsamda yapılan deneysel çalışmalar değerlendirildiğinde, derin deniz deșarjı tesisiyle Karadeniz'e deşarj edilen maden atık çamurlarının denizin tabanına doğru hareket eden bir atık olduğu (negatifyüzerliliğe sahip veya batan atık), anoksik bölgeden oksijenli bölgeye yükselemediği belirlenmiş̧tir.

\section{$\underline{\text { Anahtar Sözcükler }}$}

Maden Atıkları, Maden Atık Çamuru (Sulu Çamur), Denizaltı Depolama Yöntemi

\section{Submarine Disposal Method of Mine Tailings (Slurry Sludge)}

\begin{abstract}
The mining industry is one of the most important industrial activities that are playing a role to development of the modern society and at same time, this industry is the world's largest waste-producing industry. The raw materials, which are needed for the developing technology and industrial activities, are obtained from naturel sources with the mine activities. These mine activities can lead to destruction of biological diversity and environmental pollution problems. According to the abandonment of mining activities not possible, these activities should also be more sensitive to protection of natural sources and prevention of environmental pollution. The appropriate disposal methods and application of various engineering techniques should be investigated for this purpose. Mine waste sludge (or slurry sludge) which is produced from ore process generally is disposal in on-land storage facilities. The various environmental problems can arise due to acid mine drainage (due to sulfite oxidation), geotechnical stability and some other reasons in on-land storage areas. Due to negative effects of on-land storage facilities on the environment, mine tailings (or mine waste sludge) disposal in the receiving environments such as submarine, under constant reduction conditions and geochemically stable sulphite minerals, can see as a new and safer alternative method to land storage facilities. In this study, general disposal methods (especially submarine disposal method) were investigated for mine waste sludge or mine tailings that are forming from ore process. Possible positive and negative environmental effects of this method were discussed. Submarine disposal plant of mine tailings (for the Black Sea) in Turkey and studies to determine the effects of this discharge were evaluated. According to the results of these experimental studies, the mine tailings (or mine waste sludge) which is discharged to Black Sea are defined as a negative buoyancy waste because of it moved to bottom of the sea and could not to reach the strata where living organisms from the anoxic zone.
\end{abstract}

\section{$\underline{\text { Keywords }}$}

Mine Wastes, Mine Tailings (Slurry Sludge), Submarine Disposal Method 


\section{Giriş}

Endüstrilerde üretim yapmak için gerekli olan hammaddeler çoğu itibariyle doğal kaynaklardan sağlanmaktadır. Bu doğal (yer altı) kaynakların en önemlilerinden biri de madenlerdir. Yerkabuğunda bulunan madenlerin çıkarılma işlemleri doğal dengeyi bozan ve çevreyi kirleten işlemlerdir. Gelişen teknolojiler ve nüfus artışı dolayısıyla madencilikte üretim miktarlarında ve üretim faaliyetlerinin çeşitliliğinde ciddi artışlar olmaktadır. Bununla birlikte, yaşanan teknolojik gelişmeler, daha önceden değerlendirilemeyen madenlerin (yeryüzündeki derin madenler, derin deniz diplerindeki kaynaklar, kompleks cevherler, düşük tenörlü cevherler gibi) değerlendirilmesini/işletilmesini mümkün hale getirebilmektedir (Karadeniz 1996; Dold 2014).

Yerkabuğunda bulunan elementlerin özel bir takım fiziko-kimyasal şartlar altında bir araya gelmesiyle mineraller oluşurlar. Ekonomik değer taşıyan bu minerallerin bir veya daha fazlasının yer kabuğunda oluşturdukları birikimlere ise maden yatağ $\mathrm{ad}_{1}$ verilir. Maden yataklarının işletilmesi sonucunda da maden ocağ ${ }_{1}$ veya işletmesi ortaya çıkar. Uygun teknolojiler sayesinde insanlığın kullanımına sunularak ekonomiye kazandırılan bu mineral grupları veya kayaçlara maden adı verilir (Bağırsakç1 2000). Diğer bir tanım ise 21 Eylül 2017 tarih ve 30187 sayılı resmi gazetede Enerji ve Tabii Kaynaklar Bakanlığından tarafından yayınlanan Maden Yönetmeliği'nde yapılmıştır. Maden Yönetmeliği Madde 2'de yer alan tanıma göre "Yer kabuğunda ve su kaynaklarında tabii olarak bulunan, ekonomik ve ticarî değeri olan petrol, doğal gaz, jeotermal ve su kaynakları dışında kalan her türlü madde maden sayılır (URL-1 2017).

Madencilik faaliyetleri tüm endüstri kollarının temellerindendir (Atmaca 2001; Acar 2007). Dünya ekonomisinin hammadde ihtiyacının \%70'ini madencilik, \%30’unu tarım sektörü karşılamaktadır. Bir maden, endüstriyel tesislere hammadde olarak gelinceye kadar; arama, tespit ve hazırlık aşaması, cevher üretimi (yeraltı, açık), ekonomik minerali ekonomik olmayandan ayırma (zenginleştirme), izabe (metalürjik işlemler) gibi aşamalardan geçmek zorundadır (Karadeniz 1996). Bu aşamaların her birinde yapılan madencilik faaliyetlerinde atık/ürün oranına bağlı olarak büyük miktarlarda atık oluşmaktadır (Karadeniz 1996; Çetiner vd. 2006). Avrupa Birliğinde (AB) madencilik faaliyetleri sonucu oluşan atık miktarı, yıllık atık miktarının \%29'unu oluşturmaktadır. Maden atıkları genel olarak üst toprak, örtü kazı (dekapaj-pasa), atık kaya ve zenginleştirme atıklarından (sulu çamur) meydana gelmektedir (Çetiner vd. 2006).

\section{Maden Atığı Çamurun Bertaraf Yöntemleri}

Maden atıklarından olan sulu çamur (maden atık çamuru), özellikle metal madenciliğinde cevher zenginleştirme işlemlerinde değerli mineralleri cevherden ayırmak için uygulanan fiziksel, kimyasal, fiziko-kimyasal ve biyolojik işlemlere bağlı olarak oluşan ve içerisinde ince taneli parçacıklar ile kimyasal reaktiflerin (kimyasal işlemlerin uygulandığı proseslerde) yer aldığı tipik olarak katı ve sıvı fazın birlikte yer aldığı maden atığıdır (Çetiner vd. 2006; Vogt 2012; Shepherd vd. 2018). Bu atıkların, içeriğinde bulunma ihtimali olan ağır metaller, siyanür ve kimyasal reaktifleri, sülfür bileşikleri gibi toksik maddeler ile askıda ve çökebilen katılardan dolayı nereye ve nasıl depolanacağı çok önemlidir. Ayrıca bu atık çamurlarının nereye ve nasıl depolanacağı kadar depolama alanlarının duraylılığı ve emniyeti de önemlidir (Çetiner vd. 2006; Vogt 2012). Madencilik faaliyetleri sonucunda oluşan farklı özelliklerdeki (miktar, boyut, mineraloji vb.) atıklar, bu faaliyetler esnasında, yer altı ocaklarında, atık baraj seti yapımında veya suyollarının düzenlenmesinde dolgu malzemesi olarak kullanılabilirler. Ayrıca, maden atık çamurlarının içeriğinde bulunabilen ağır metallerin çöktürülmesi, siyanürün parçalanması ve asidin nötralizasyonu gibi özel uygulamalarla da atıkların bertarafı sağlanabilir (Arol 2002). Madencilik tesislerinde işlemler genellikle proses suyu kullanılarak yapılır (Yüce 2012). Madencilik faaliyetleri sonucu oluşan tüm atıkların bertarafında atığın türü, uygulanan yöntem, atığın yeri, yerleşimi, yapım biçimi ve su deşarjı önemlidir. Bu parametreler göz önüne alınarak genel olarak uygulanan atık çamur bertaraf yöntemleri; atık barajlarında bertaraf, yer altı ocaklarında bertaraf, nehir ve göl deşarjı, denizaltı depolama yöntemleridir.

\subsection{Yerüstü Atık Barajlarında Bertaraf Yöntemi}

Maden atıklarının veya atık çamurlarının \%99.4'ü yerüstü atık barajlarında ve sadece \%0.6'sı deniz ortamında depolanmaktadır. Maden atıklarının veya atık çamurlarının yerüstü atık barajlarında uzun süreli/kalıcı olarak bertaraf edilmesi için vadi veya yamaç barajları ile özel olarak inşa edilmiş atık bentleri/barajları gibi yerüstünde bulunan/inşa edilen yapılar kullanılmaktadır. Atık kayalar veya üst örtü atıkları genelde arazi üzerinde depolanırlar, fakat bazen açık maden ocaklarına doldurulabilirler (Vogt 2012; Trannum vd. 2018). Şekil 1'te çeşitli yerüstü atık barajı örnekleri verilmiştir. 

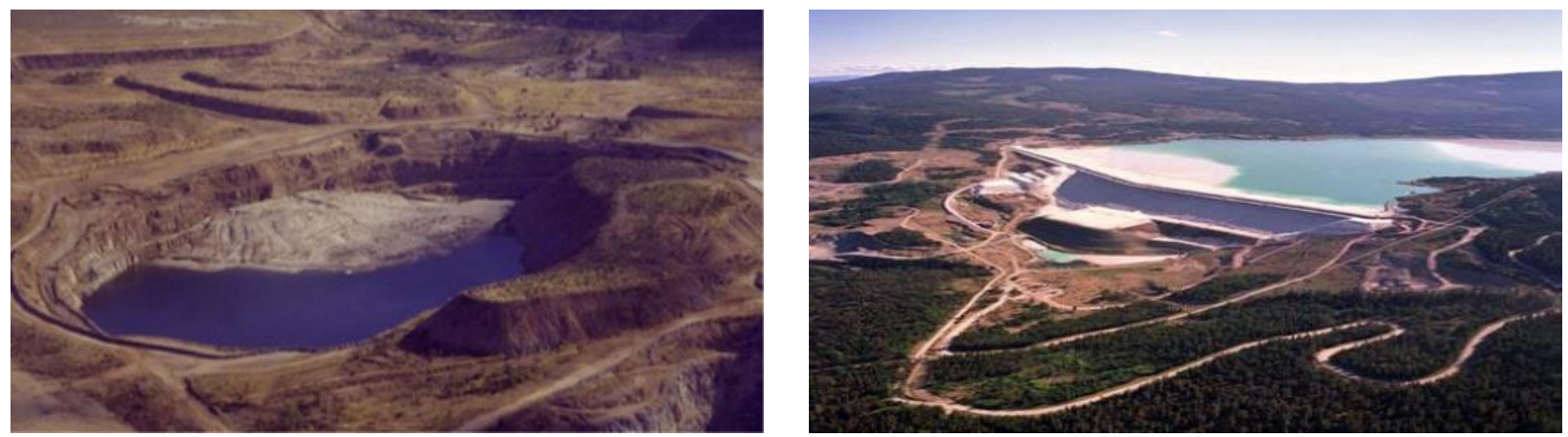

Şekil 1: Atık barajı resimleri (Vogt 2012)

Dünya genelinde yaklaşık 3500 adet atık barajı bulunduğu bilinmekte ve bu barajların çoğunluğu Uluslararası Büyük Barajlar Komitesi (ICOLD) tarafindan takip edilmektedir (Vogt 2012). Son yıllarda bu barajlarda meydana gelen kazalar bu barajların güvenilirliğini ve uzun süre işletilebilirliğini sorgular hale getirmiştir. Uluslararası Büyük Barajlar Komitesi'nin bir çalışmasında, 500 kadar atık barajının \%24'ünün yenilenme-yıkılmasının gerektiği, \%42'sinin onarım gerektirecek boyutta hasarlı olduğu ve \%34'ünün de kaza oluşturabilecek boyutunda hasarlı olduğu belirtilmektedir. Baraj yıkılmalarının büyük bölümü taşkınlar dolayısıyla oluşmaktadır. Barajlarda oluşan hasarların büyük bölümünün ise savak ve öteki yapılardaki sorunlardan kaynaklandığı belirlenmiştir. İncelemeler dolduğu için kapatılıp terkedilmiş birçok barajda da bu tür sorunlar yaşandığını göstermektedir. En sık karşılaşılan hasar nedenleri toplu duraysızlaşma (kayma), taşkın ve depremdir. Atık barajlarında meydana gelen kazalar sonucunda çok ciddi can kayıpları meydana gelmiştir. Özellikle 1985 'te İtalya'da bir fluorit işletmesinin barajında göçme yaşanmış ve 268 kişinin ölümüne neden olmuştur. Yine 2010 yılında Macaristan'da meydana gelen olayda 10 kişi yaşamını yitirmiş ve 120 kişi yaralanmıştır. Ayrıca bu olayda yaklaşık 700 bin $\mathrm{m}^{3}$ kırmızı çamur ve su, atık barajından çıkarak bir çevre felaketi oluşturmuştur (URL-2 2001; Vogt 2012). Şekil 2'de atık çamur barajlarında oluşan bazı olumsuz olaylar ve sonucunda oluşan durumlar için örnekler verilmiştir.
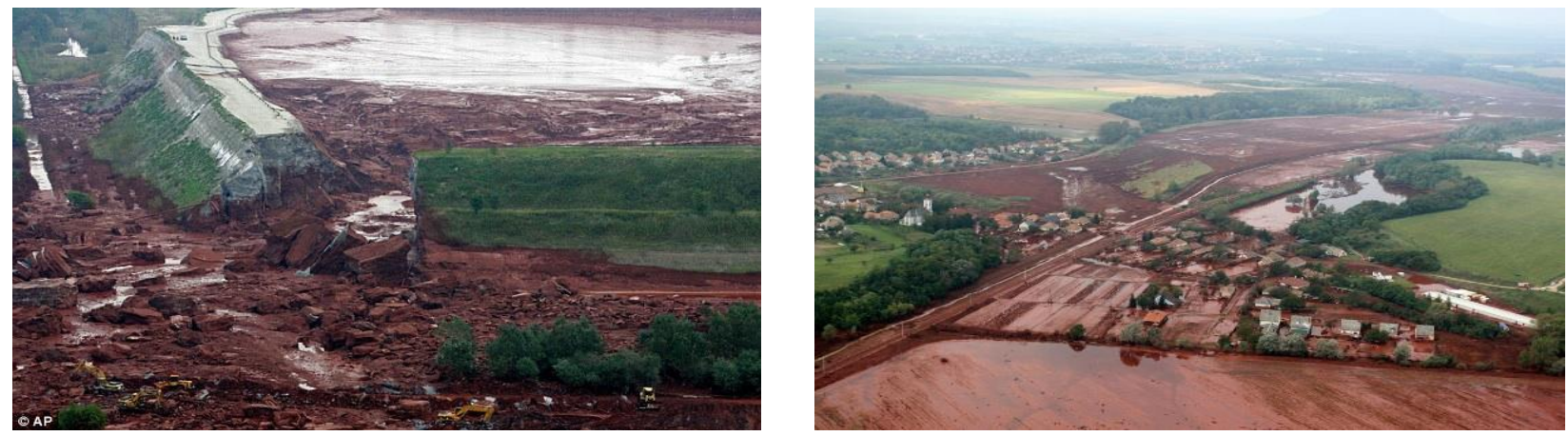

Şekil 2: Atık barajı taşkın örneği (Macaristan) (URL-3 2010)

\subsection{Yeraltı Ocaklarında Bertaraf Yöntemi}

Maden atıklarının bertaraf edilmesinde yaygın olarak uygulanan yöntemlerden biri de yeraltı maden işletmelerinde, madenin çıkarılmasıyla oluşan boşluklara, tesis atıklarının çeşitli yöntemler ile doldurulması işlemidir. Yeraltından madeni çıkardıktan sonra yeraltında çeşitli hacimlerde boşluklar oluşur. Oluşan bu boşluklar yüzeyde çöküntü (tasman) ve kaymalara neden olabilir. Dolayısıyla hem bu çöküntüleri önlemek hem de çalışanların güvenliğini sağlamak için oluşan boşluklara dolgu yapılması gerekir (Karadeniz 1996). Dolgu için gerekli olan dolgu malzemeleri maden atıklarından elde edilebilir. Ayrıca son zamanlarda, macun dolgu adı verilen basınçlı filtre ile suyu iyice alınmış ve çimento katkılı kuru çamurlar da hem tahkimat hem de atık bertarafını sağladığı için başarıyla uygulanmaktadır (Archibald 1999; Arol 2002). Maden atıklarının yeraltında üretimi tamamlanmış boşluklarda dolgu malzemesi olarak kullanılmasında dikkat edilmesi gereken önemli hususlardan biri de yer altı sularının kirletilmemesidir (Vogt 2012). Şekil 3 'te atık çamurların yeraltı ocaklarında depolanmasına örnek bir resim verilmiştir. 


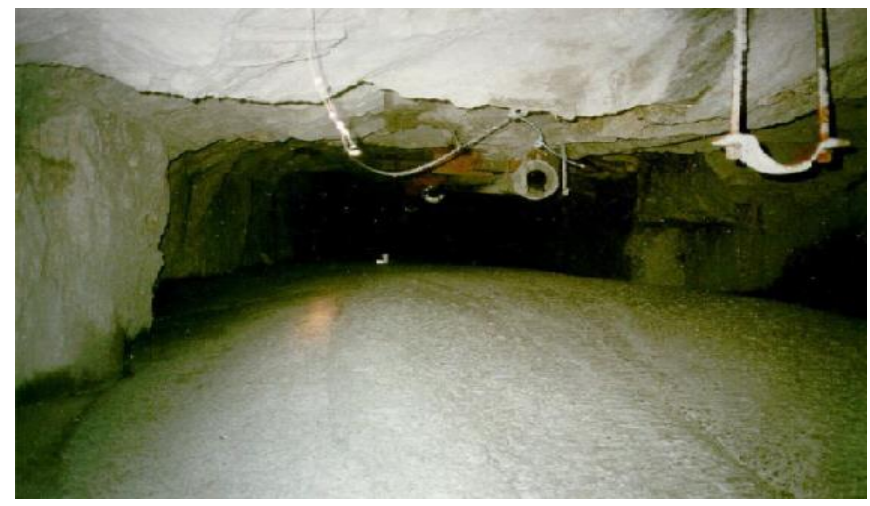

Şekil 3: Maden atık çamurların yeraltı ocaklarında depolanması (Topçu 2012)

\subsection{Nehir ve Göllere Deşarj Yöntemi}

Maden atık çamurlarıın nehir ve göllere deşarjı, geçmişte yaygın olarak kullanılsa da günümüzde sınırlı sayıda bazı işletmeler dışında yaygın olarak kullanılmamaktadır. Bu yöntem, özellikle nehir kenar ve ağızlarında birikim yaparak alüvyon tabaka oluşturması, kirliliği uzak noktalara taşıması ve küçük nehirlerin maden atık çamurlarının hacimlerini taşıyamaz halde olması gibi sebeplerden günümüzde pek tercih edilmemektedir (Karadeniz 1996; Arol 2002). Maden atıklarının nehirlerde meydana getirdiği olumsuz etkilere rağmen Endonezya ve Papua Yeni Gine de bulunan 4 madende hala nehre deşarj yapılmaktadır. Bu ülkeler atık barajı yapımının geoteknik, deprem riski ve yüksek yağış nedeniyle imkânsız olduğunu ifade etmektedirler (Vogt 2012). Maden atık çamurlarının göllere deşarj edilmesini kısıtlayan unsurlardan biri göllerin, denizler ve okyanuslar gibi büyük hacimli olmaması nedeniyle bünyelerinde özümleyecekleri madde miktarlarının oldukça sınırlı olmasıdır. Ayrıca, bazı maden atık çamurlarının yüksek toksisiteye sahip olması, bu yöntemin bertaraf yöntemi olarak kullanılmasını kısıtlamaktadır. Göllerde yaşayan balıklar ve diğer mikroorganizmalar için maden atık çamurlarının içerisinde yer alan maddeler ya birikim yaparak veya ortamda bulunan oksijeni tüketerek (sülfürlü bileşiklerin oksijenle reaksiyona girmesi sonucunda) yaşamsal tehlikeler oluşturmaktadır. Bunlara ilaveten sülfürlü bileşiklerin oksijenle reaksiyona girmesi sonucu oluşan asitlerde ciddi sorunlar oluşturmaktadır (Karadeniz 1996).

\subsection{Denizaltı Depolama Yöntemi}

Maden atık çamurlarının güvenli bir şekilde bertaraf edilmesi dünya genelinde madencilik endüstrisini zorlayan en önemli çevre sorunudur. Aynı zamanda atık bertaraf işlemleri maden işletmelerinin en büyük masraflarını oluşturmaktadırlar. Madencilik faaliyetleri esnasında çok yüksek bir atık/ürün oranı oluştuğu bilinmektedir (Çetiner vd. 2006). Bu oran; demir için \%60, bakır için \%99 iken altın için \%99.99'dur (Vogt 2012). Bu şekildeki özellikle su içeriği fazla olan maden atık çamurlarının yerüstü atık barajlarında güvenli bir şekilde depolanması hem oldukça zor (sızma, kırılma vb.) hem de bazı maden atıklarının içerdiği zehirli bileşikler nedeniyle çevresel açıdan büyük riskler taşımaktadır. Maden atık çamurlarının içerisinde yer alabilen metaller genel olarak sülfür bileşikleri halindedirler. Atık çamurda bulunan metal sülfürler hava ve su ile temas ettiklerinde sülfürik asit oluşturarak asit maden drenajlarına yol açarlar (Dold 2014). Sülfürik asit oluşmasıyla maden atık çamurunda bulunan metallerin çözülmesi de hızlanır. Dolayısıyla asit maden drenajları maden çevresinde, toprakta ve yüzeysel sularda olumsuz etkilere neden olabilirler.

Maden atık çamurlarının denize atılması ya da deşarj edilmesi madenciliğin ilk günlerinden itibaren dünyanın birçok yerinde uygulanmıştır (Çetiner vd. 2006; Kayhan 2008; Dold 2014). Özellikle yerüstü atık barajlarında depolamanın riskli, yağış miktarının fazla ve buharlaşmanın az olduğu yerlerde maden atı̆̆ çamurun denize deşarjı alternatif bir bertaraf yöntemi olarak uygulanmaktadır (Çetiner vd. 2006; Dold 2014). Bu bertaraf yönteminde, kıyıdan yapılan deşarjdan, uzun boru hatlarıyla derin denizaltına deşarj sistemine kadar değişik yöntemler uygulanmıştır. Maden atığ çamurun sığ sulara deşarjı dünyada yaklaşık olarak yüz yıldan beri uygulanmaktadır (Baer vd. 1992). Bu uygulamanın başladığı ilk yıllarda atık çamur plansız olarak denize deşarj edilmekteydi. Yüzeyden direkt denize yapılan bu deşarjın kıyısal alanlarda kirliliğe ve sucul canlıları olumsuz etkilenmesi nedeniyle 1970 yılından itibaren zamanla birkaç on metreden yüzlerce metre uzunluklara ulaşan boru hatlarıyla deşarjların yapılması sonucunda daha sofistike yöntemlere dönüşmüştür (Ramirez-Llodra vd. 2015). Maden atıklarının deniz ortamındaki çevresel etkileri azaltmak için deşarjın daha derinlere doğru indirilmesi sı̆̆, orta ve derin denizaltı deşarj tanımlamalarını ortaya çıkarmıştır (sı̆̆ derinlik, 0-200 m, orta derinlik, 200-1000 m ve derin, 1000 m'den daha fazla) (GESAMP 2016; Ramirez-Llodra vd. 2015; Vare vd. 2018). Derin denizaltı bertaraf konsepti ise, genellikle 100-300 m'ye kadar uzatılmış bir deşarj noktasından $1000 \mathrm{~m}$ veya daha yüksek bir son depolanma derinliğine ve ötrofik yüzey karıştırma bölgesinin altındaki bir derinlik deşarjına dayanır (Ellis ve Ellis 1994). 
Maden atık çamurlarının daha derinlere depolanmasını sağlamak için, deşarj noktasının konumu deşarj hattından çıkan atık çamurun istenilen tabana ulaşana kadar stabil-kararlı bir yoğunluk akıntısı oluşturacak ve minimum dağılmayı/yayılımı sağlayacak yerde olmalıdır. Denizaltı kanyonlarının bu tip derin denizaltı depolamaları için uygun olduğu düşünülmektedir (Reichelt-Brushett 2012). Ayrıca, maden atığı çamurun denizaltı depolama ile bertarafı özellikle Karadeniz'in anoksik bölgesi gibi sucul yaşamın olmadığı alanlarda, yüzeysel depolamayla oluşan görsel kirlilik, atık barajlarının bakımı, asit maden drenajları, metal süzüntüleri ve oluşabilecek kazalarında önlenebilmesine olanak sağlayacağı ileri sürülmektedir. Bununla birlikte, bu yöntem Karadeniz'in anoksik bölgesi gibi bazı özel bölgeler için uygulanabilir bulunsa da, bu atıkların inert ve deniz dibinde herhangi bir olumsuzluk oluşturmayacağı bilimsel olarak belirlendikten sonra deşarj edilmesi ve bu deşarjın zamanla oluşturabileceği herhangi bir olumsuz etkilere karşın sürekli izlenmesi çevresel sorunların oluşumunu önleme açısından gereklidir.

\subsubsection{Maden Atığı Çamurun Denizaltı Depolama Uygulamaları}

Maden atığı çamurun denizaltı depolama uygulamaları dünya genelinde 2012 yılı itibariyle 11 nokta da (14 noktadan 3 'ü kullanılmadığından) devam etmektedir. Bunlardan 5 adedi Norveç’te, 3 adedi Papua Yeni Gine'de, 1'er adette Türkiye (Çayeli-Rize), Fransa, Yunanistan, Şili, İngiltere ve Endonezya'da bulunmaktadır (Dold 2014; Vogt 2012). Tablo 1'de dünya genelinde denizaltı depolama yönteminin uygulandığı tesisler verilmiştir. Türkiye'de Rize-Çayeli-Madenköy kasabasında bulunan Çayeli Bakır İşletmeleri (ÇBİ) maden atık çamurları, Karadeniz'in yüzeyden 275 m altına deşarj edilerek bertaraf edilmektedir.

Karadeniz'de yüzeyden -175 metrenin altındaki su kütlesinin oksijen değerlerinin tamamen minimize olması ve ortamın kükürtlü hidrojen gazı ile doymuş hali maden atığı çamurun Karadeniz'e deşarj edilmesine imkân sağlamaktadır. Bu katmanda sıcaklık ve tuzluluğun son derece homojen olduğu ve mevsimsel değişimlerden etkilemediği yapılan çeşitli araştırmalarda görülmüştür (İzdar 2009). Karadeniz'in derin sularındaki hidrojen sülfürün varlığı, çözünebilen ağır metallerin metal sülfite indirgenerek pirit veya benzeri mineraller halinde çökelmesini sağlamaktadır. Diğer taraftan deniz tabanındaki kil özelliğindeki ince materyal çözünebilen ağır metallerin tutulmasını sağlayan bir ortam oluşturmaktadır. Karadeniz'in kalınlığ 2000 m'yi aşan oksijensiz dip sularında normal deniz canlıları yaşamamaktadır. Diğer bir ifade ile anaerobik yaşam türleri dışında oksijene ihtiyaç duyan deniz canlıları bulunmamaktadır. Karadeniz'e gönderilen atıksuların depolanabilirliğini sağlamak için göz önünde bulundurulması gereken en önemli husus deşarj noktasının tamamen oksijensiz ortam içinde bulunması ve oksijenli katmanın karışım etkisinden korunmasıdır. Yine Temmuz 2015'de yayınlanan Maden Atıkları Yönetmeliği'ne (URL-4 2015) göre de inert ve tehlikesiz olarak tanımlanan maden atıklarının sadece Karadeniz'in bu katmanına belirli kriterleri sağlamak şartıyla deşarj edilebileceği ifade edilmiştir.

1993 yılında kurulan Çayeli Bakır İşletmeleri (ÇBİ) Türkiye'nin en büyük bakır ve çinko üreticisidir. Tesis, maden zenginleştirme prosesinden çıkan flotasyon atık çamurunu Karadeniz'in $275 \mathrm{~m}$ derinliğindeki anoksik sularına deşarj etmektedir. 1994 yılında faaliyete başlayan ÇBİ, 2002 yılına kadar zenginleştirme işleminden çıkan atık sularını kıyıdan $3200 \mathrm{~m}$ açıkta ve $385 \mathrm{~m}$ derine deşarj etmekteydi. 2001 yılı sonundan itibaren boru hattının özellikle son 100 m'lik bölümünde teknik problemlerin varlığı ortaya çıkmış ve yapılan çalışmalarda, $385 \mathrm{~m}$ deki basınç nedeniyle boru hattının yassılaştığ1 ve buna bağlı olarak da kapasitesinde büyük bir düşmenin olduğu tespit edilmiştir. Çözüm olarak da boru hattının derinlik olarak yaklaşık 100 m kısaltılması gündeme gelmiş ve bu konuda detaylı mühendislik ve çevresel etki değerlendirme çalışmaları yapılmıştır. Bölgede yapılan izleme çalışmalarında, atık suyun daha sığ bir noktaya deşarj edilmesiyle çevresel etki açısından herhangi bir değişikliğin olmayacağı belirlenmiş ve 2002 yılından itibaren söz konusu atık çamur 275 m derinliğe ve kıyıdan 3000 m açıklara deşarj edilmeye başlanmıştır (İzdar 2009; Ünsal 2002).

\subsubsection{Maden Atık Çamurunun Denizaltı (Karadeniz’e) Deşarjı İçin Yapılan Deneysel Çalışmalar}

Maden Atıkları Yönetmeliği’ne (URL-4 2015) göre “ Maden atıkların toprağa, denizlere, göllere, akarsulara ve benzeri alıcı ortamlara dökülmesi, doğrudan dolgu yapılması ve depolanması suretiyle çevrenin kirletilmesi yasaktır” (Madde 5(2). Yine aynı yönetmelik Madde 22 (1)'de “Atık Karakterizasyonu sonucunda, tehlikeli olarak tanımlanan maden atıkları ülkemizdeki denizlerde kesinlikle bertaraf edilemez" ifadeleri yer almaktadır. Dolayısıyla maden atık çamurlarının da bu maddeler kapsamında deniz ya da herhangi bir alıcı ortama deşarj edilmesi yasaklanmıştır. Ancak, yönetmeliğin Madde 22 (2) verilen "Atık Karakterizasyonu sonucunda, inert ve tehlikesiz olarak tanımlanan maden atıkları sadece Karadeniz'in oksijen içermeyen ve canlı yaşamı olmayan ölü tabakasında bertaraf edilir” ifadesine göre bazı istisnalar tanımlanmıştır. Bu kapsamda, Karadeniz'e maden atıklarından olan çamuru derin deşarj ederek bertaraf eden ülkemizdeki tek tesis, Çayeli Bakır İşletmeleridir. ÇBİ ve ilerde Karadeniz’e benzer şekilde deşarj yapmayı planlayan tesislerin inert ve tehlikesiz atıkları için çevresel izleme ve kontroller açısından aynı yönetmeliğin Madde 22 (4)'te çeşitli çalışmaların yaptırılması ve raporlanarak Çevre ve Şehircilik Bakanlığı'na sunulması zorunluluğu getirilmiştir. Bu madde kapsamında belirlenmesi gereken parametrelerden biri de atığın deniz ortamında çökelme ve yükselme aralığıdır. ÇBİ ve benzeri atık karakterizasyonuna sahip maden tesisleri için ülkemiz üniversitelerinde bu yönetmelik hazırlanmadan önce gerek ilgili kurumun isteği ve gerekse bilimsel amaçlı olarak çeşitli tezler, raporlar ve araştırma çalışmaları yapılmıştır. Bu çalışmada, ÇBİnin atık karakterizasyonunu yansıtan maden atık çamurları için laboratuvar ortamında yapılan deneysel çalışmaların sonuçları değerlendirilmiştir. Bu kapsamda, Karadeniz Teknik Üniversitesi'nde (KTÜ) 2001, İstanbul Teknik Üniversitesi'nde (İTÜ) 2002 ve İstanbul Üniversitesi (İ̈) Çevre 
Mühendisliği Bölümünde 2013 yıllarında laboratuvar ortamında yapılan deneysel çalışmaların sonuçları verilmiştir. Bu çalışmalarda, maden atığı çamuru karakterize etmek için ya yoğunluk ayarlaması yapılmış veya gerçek atık çamur numunesi kullanılmıştır. KTÜ ve İTÜ yapılan deneysel modelleme çalışmalarına göre;

- Çayeli Bakır İşletmelerinin Karadeniz’e deşarj edilen atık çamurlarının özgül ağırlığının $\left(1.0610\right.$ ton $\left./ \mathrm{m}^{3}\right)$ alıcı ortamın özgül ağırlığından (1.0167 ton $/ \mathrm{m}^{3} ; 250 \mathrm{~m}$ derinlikteki değer) çok büyük olması nedeniyle deniz tabanına doğru hareket eden (negatif yüzerliliğe sahip batan) jet olduğu (Ünsal 2002),

- Atık çamurun deşarj yapıldığı bölgenin 350 m derinliğe kadar türbülans, yukarı doğru karışma ve akıntı açısından sakin kabul edilebilecek koşullar altında bulunduğu (Berkün ve Önsoy 2001),

- $250 \mathrm{~m}$ derinliğin çevre koșulları ve ortamın özelliklerinin $350 \mathrm{~m}$ derinliğin koşul ve özellikleri ile benzeșim içinde olduğu (Berkün ve Önsoy 2001),

- $\quad$ En kötü koşullarda bile, atığın sadece 67 m yükselebileceği ve yine Karadeniz’in oksijensiz bölgesinde kalacağ1 ve bu süre zarfinda $355 \mathrm{kez}$ seyreleceğinin tespit edildiği belirtilmiştir (ÇBİ 2013). Şekil 4'de sırasıyla laboratuvar ortamında bulunan bir tank içerisinde KTÜ ve İTÜ'de yapılan deneysel çalışma düzeneklerine ait resimler verilmiştir.

Tablo 1: Denizaltı deşarj ve depolama yapan madenler ve atık miktarları (Vogt 2012)

\begin{tabular}{|c|c|c|c|c|}
\hline Ülke/Yer & Maden Tipi & Maden Atığı (ton/yıl) & Derinlik (m) & Şirket \\
\hline \multicolumn{5}{|c|}{ Endonezya } \\
\hline Batu Hijau & Altın/Bakır & 40000000 & $3000-4000$ & Newmont Mining \\
\hline \multicolumn{5}{|c|}{ Papua Yeni Gine } \\
\hline Lihir & Altın & 4000000 & $>2000$ & Newcrest \\
\hline Lihir & & 44000000 (atık kaya) & Denizaşırı $1 \mathrm{~km}$ & Newcrest \\
\hline Simberi & Altın & 3300000 & Kullanılmamaktadır & Allied Gold \\
\hline Ramu Nickel & Nikel/Kobalt & 5000000 & 1500 & Met. Co. China/H. Pacific \\
\hline \multicolumn{5}{|c|}{ Türkiye } \\
\hline Çayeli Bakır & Bakır/Çinko & 11000000 & $>2000$ & Inmet Mining \\
\hline \multicolumn{5}{|c|}{ İngiltere } \\
\hline Boulby & Potasyum & 1800000 & Kullanılmamaktadır & Cleveland Potash \\
\hline \multicolumn{5}{|c|}{ Norveç } \\
\hline Bokfjorden & Demir & 4000000 & 220 & Sydvaranger (NorthernIron Ltd.) \\
\hline Ranafjorden & Demir & 2000000 & 80 & Rana Gruber Minerals \\
\hline Stjernoy & Nefelinli Siyanit & Yaklaşık 300000 & Kullanılmamaktadır & Sibelco Nordic \\
\hline Elnesvagen & Pigmentler & 500000 & & Hustadmarmor \\
\hline Skaland & Grafit & $20000-40000$ & 30 & Skaland Graphite ASA \\
\hline \multicolumn{5}{|c|}{ Fransa } \\
\hline Gardanne & Alüminyum & & 330 & Rio Tinto Alcan \\
\hline \multicolumn{5}{|c|}{ Yunanistan } \\
\hline $\begin{array}{l}\text { Agios } \\
\text { Nikolaos }\end{array}$ & Alüminyum & & 800 & Aluminum of Greece \\
\hline \multicolumn{5}{|c|}{ Şili } \\
\hline Husaco & Demir & 1200000 & 35 & CAP Mineria \\
\hline
\end{tabular}




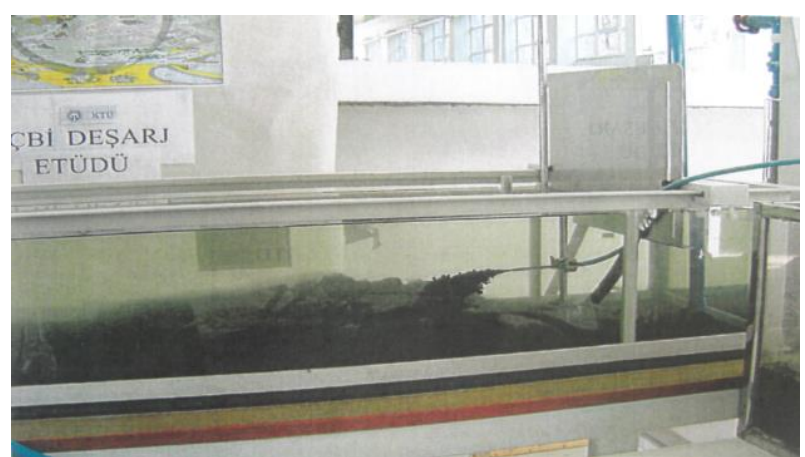

a) KTÜ'de (Berkün ve Önsoy 2001)

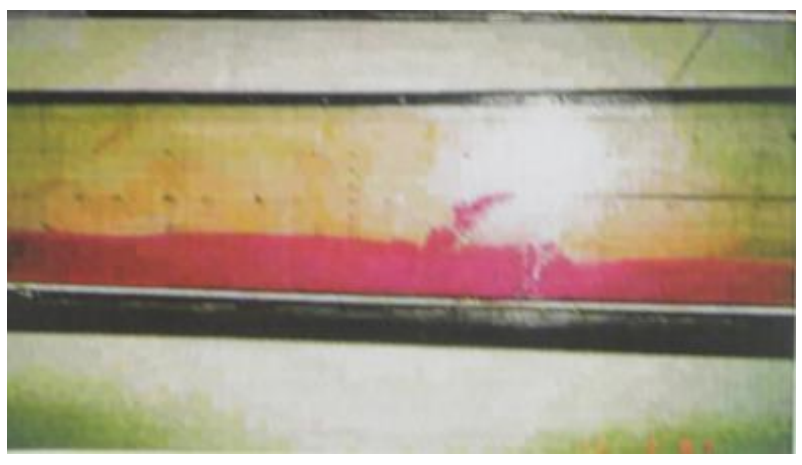

b) ITÜ'de (Ünsal 2002)

Şekil 4: ÇBi atık çamurlarının Karadeniz’e deşarjı için yapılan deneysel çalışma düzenekleri

İstanbul Üniversitesi Çevre Mühendisliği Bölümünde yapılan çalışmada, Çayeli Bakır İşletmeleri’nin derin deniz deşarjı yaptıkları bölgede deniz tabanı eğimli olduğundan, deneyde $16.7^{\circ}$ eğimli pleksiglas taban kullanılmıştır. Literatürde verilen ÇBİ atık çamur yoğunluğuna uygun atıksular ve alıcı ortam yoğunluğu ayarlanarak İnce vd. (2013) tarafindan yapılan deneysel çalışmalar sonucunda;

- Atıksu jetinin hiçbir parçasının yukarı yönlenmediği, dolayısıyla söz konusu alıcı ortam ve deşarj şartlarında atık çamur kütlesinin Karadeniz'in anoksik olan bölgesinin üzerine çıkmayacağı, bu sayede de oksijenli bölgede yaşayan canlılar açısından tehlike oluşturmayacağı,

- Atık çamur kütlesinin çarpma noktasından sonra yoğunluk akıntısına dönüştüğü ve uzak mesafede eğimli yüzey üzerinde kalınlığının sürekli olarak arttığı ve bunun sonucunda da alıcı ortam suyuna karışarak seyrelmeyi arttırdığı belirlenmiştir. Bununla birlikte, atıksuyun kalınlığının arttığı bölgelerde bile bu kalınlık artışının kesinlikle yukarı yönlü bir harekete neden olmadığı, sonuç olarak doğal eğime sahip yüzey üzerinde atık çamur/atıksu hareket ederken hiçbir koşulda deşarj noktası üst yüzey koordinatının üzerine geçmediği,

- Atık çamur kütlesi en kesiti boyunca konsantrasyonların yanal olarak azaldığı yani kaynaktan uzaklaşıldıkça kirlilik ulaşma riskinin de azaldığ 1 tespit edilmiştir.

İstanbul Üniversitesi (İ̈̈) Çevre Mühendisliği Bölümünde yapılan çalışmada kullanılan deney düzeneğine ait resimler Şekil 5'de verilmiştir.

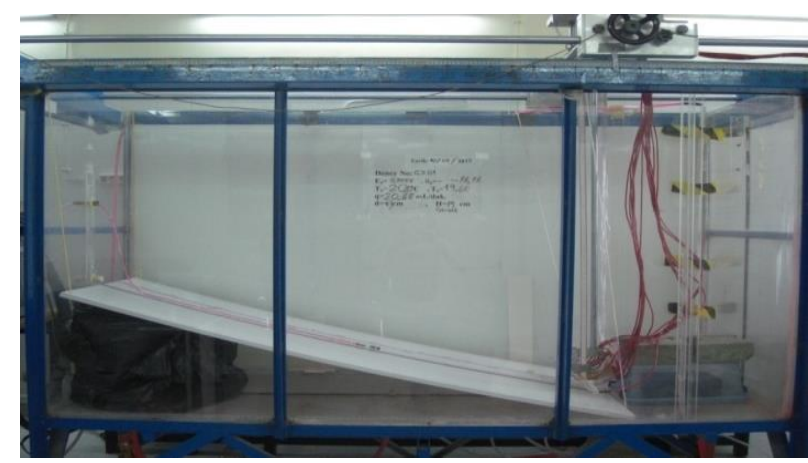

a) Genel görünüm

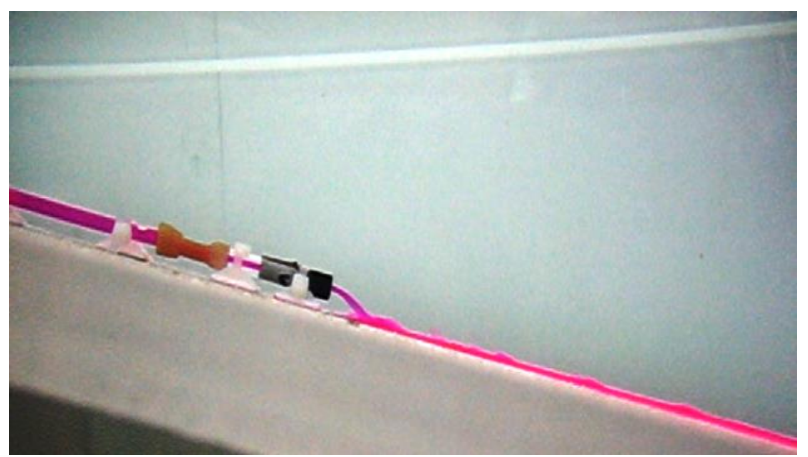

b)Yakın çekim

Şekil 5: IÜ’ de yapılan deşarj çalışma düzeneği (İnce vd. 2013)

\subsubsection{Denizaltı Depolama Yönteminin Avantaj ve Dezavantajları}

Maden atık çamurlarının denizlere deşarj edilmesiyle bertarafı eskiden de uygulanan bir yöntem olmasına rağmen, son yıllarda yerüstü depolama alanları olan atık barajlarında meydana gelen kazalardan dolayı derin deniz altlarına depolanması yeniden tartışılmaya başlanmıştır. Bu konuda yükseklikleri bazen yüz metreleri bulan atık barajlarına karşı halkın gösterdiği tepkilerde etkili olmuştur. Yeniden gündeme gelen maden atık çamurlarının denizaltına depolanmasının yaygın avantaj ve dezavantajları aşağıda verilmiştir (Dold 2014).

Avantajları;

- Deniz suyunun tamponlama kapasitesi ile atık çamur içerisindeki sülfürün oksidasyonunun nötralize edilmesi (bu sayede yerüstü atık barajları ile bertaraf yöntemlerinde oluşan asit maden drenajının önlenmesi sağlanmış olacaktır), 
- Atık barajlarında sismik aktivite ve yoğun yağışlardan dolayı jeoteknik açıdan meydana gelebilecek olan çökmeler ve onun sonucunda oluşabilecek zararların önlenmesi,

- Minimal toprak yüzeyi kullanılarak özellikle Norveç'te yer alan fiyort gibi alanın sınırlı olduğu yerlerde önemli bir avantaj sağlaması,

- Atık barajları ile karşılaştırıldığında daha az ve daha uzun vadeli bakımların yapılacak olmasıdır.

Dezavantajları;

- Deniz tabanında bulunan bentik organizmaların yoğun çamurun etkisiyle yaşamının olumsuz etkilenmesi ve tabanda meydana gelen fiziksel ve jeokimyasal değişiklikler,

- Deniz topluluklarının tür ve biyolojik çeşitliliğin azalması,

- Maden atı̆̆ çamurdan deniz suyuna toksik elementlerin bırakılma riski,

- Metallerin biyoakümülasyonu ve besin zinciri ile insanlara ulaşma riski,

- Atık çamurun içerdiği suyun geri kazanılamaz oluşu (özellikle kuru iklimler sahip yerlerde önemlidir),

- Çamur içerisinde yer alan ve değerli olma ihtimali olan kaynakların geri alınamaz oluşu,

- Kullanılan flotasyon reaktiflerinin deniz ekosistemine olan olasi toksisitesi,

- İnce partikül maddelerin akıntı ve diğer etkilerle deniz boyunca dağılmasıdır.

\section{Sonuçlar}

$\mathrm{Bu}$ çalışmada, maden atıkları özelinde cevher zenginleştirme atıklarından olan çamurun bertaraf yöntemleri ve bu yöntemlerden biri olan denizaltı depolama yönteminin Karadeniz'e uygulanma örneğinde, deşarjın deniz ortamındaki davranışlarını belirlemeye yönelik laboratuvar ortamlarında yapılan deneysel çalışmaların sonuçları değerlendirilmiştir. Maden atıklarından olan çamurun bertarafı için çoğunlukla atık barajları kullanılmakta olup atık barajı inşası için arazi vb. şartların uygun olmadığı yerlerde ise yüzeysel sulara deşarjlar yapılabilmektedir. Maden atık çamurlarının kıyıdan ve yüzeye yakın yerlerden denizlere deşarj edilmesinin oluşturduğu olumsuz çevresel etkilerden dolayı bu uygulamadan son yıllarda çoğunluk itibariyle vazgeçilmiştir. Yoğun yağış alan, deprem gibi çeşitli riskler taşıyan ve tesis yakınlarında düz arazi bulunmayan Norveç, Endonezya ve Papua Yeni Gine gibi bazı ülkelerde maden atığı çamurların denize deşarj edilerek bertaraf edilme yöntemi hala uygulanmaktadır. Ayrıca, maden atığı çamurun belirli bir derinlikten sonra anoksik tabakanın başladığı ve canlı yaşamın olmadığı alıcı ortamlara (Karadeniz gibi) deşarj edilmesi de Türkiye ve Norveç gibi ülkelerde uygulanmaktadır. Maden atığı çamurun coğrafik olarak uygun olduğu yerlerde denizaltına (alıcı ortamlara) deşarj edilerek bertaraf edilmesi ekonomik olması açısından ve diğer bertaraf yöntemlerinin olası sakıncalarından dolayı avantajlı gibi gözükse de bu atıkların denize deşarj edilmesi durumunda deniz ekosisteminde oluşacak olumsuz çevresel etkiler ayrıntılı bir şekilde incelenmelidir. Özellikle sülfür oksidasyonu ve toksit maddelerin (metaller gibi) deniz canlılarında birikerek besin zincirine dâhil olma ihtimali göz ardı edilmemelidir.

Bu çalışmada, Rize Çayeli’nde bulunan Çayeli Bakır İşletmeleri atık çamurlarının Karadeniz'in tabanına uygulanan derin denizaltı deşarjı için laboratuvar ortamında yapılan deneysel çalışmaların sonuçları bir bütün halinde değerlendirilmiştir. Üç farklı üniversite tarafından yapılan laboratuvar ölçekli çalışmaların sonucunda derin deniz deşarj sistemiyle Karadeniz'e deşarj edilen atık çamurların anoksik bölgeden, canlıların yaşadığı bölgeye kesinlikle yükselmeyeceği ve deniz ortamının canlıların yaşadığı bölge açısından tehlikeler oluşturmayacağı değerlendirilmesi yapılmıştır. Ayrıca, Karadeniz'e deşarj edilen bu atığın denizin dibine doğru hareket etme eğiliminde olduğu ve Karadeniz dibinin eğimli olmasının seyrelmeyi arttırdığı tespit edilmiştir. Ancak, laboratuvar ölçekli yapılan ve kısmen gerçek alıcı ortama benzetilmeye çalışarak yapılan bu çalışmaların, deniz ortamı hidrodinamiklerinin (akıntı, basınç, deniz dibi pürüzlülüğ̈̈ vb.) tam anlamıyla deneysel çalışmalarda benzeşimi yapılamaması nedeniyle gerçek alıcı ortam şartlarına uyumluluğunu tam olarak ifade edemeyeceği aşikârdır. Bununla birlikte, bu çalışmalar bir yaklaşım oluşturulması açısından önemlidir. Benzeri atıkların deniz ortamında davranışını ve etkilerini tam anlamıyla anlayabilmek için saha ölçümleri ve sahadan alınan numunelerin analizi gereklidir. Bu tip deniz deşarjlarında uzun süreli çevresel gözlemlerin yapılması olası risklerden insan sağlı̆̆ının ve çevrenin korunması açısından önemlidir.

Sonuç olarak, maden atığı çamurun ister kıyıdan ister yüzeye yakın yerden, isterse derin yerlerden denizlere deşarjı ve depolanması dünya genelinde, oluşturduğu çevresel riskler açısından yasaklanan veya yasaklanma eğiliminde olunan uygulamalardır. Bu uygulamaların istisnasını oluşturan Karadeniz'in dip bölgesi gibi hiçbir şekilde canlı yaşamın olmadığı alanlara da, ülkemizde yürürlükte olan Maden Atıkları Yönetmeliği’ne göre, sadece tehlikesizliği ve inertliği bilimsel çalışmalarla tespit edilen, canlıların yaşadığı tabakalara ulaşmayan ve etkileri sürekli izlenen maden atığı çamurların deşarjına müsaade edilse bile gelecek yıllarda bu deşarjların nasıl bir etki oluşturabileceği hakkında daha detaylı ve kollektif çalışmalar yapılmalıdır.

\section{Teşekkür}

$\mathrm{Bu}$ çalışma İstanbul Üniversitesi-Cerrahpaşa Bilimsel Araştırma Projeleri Koordinasyon Birimi tarafindan desteklenmiştir. Proje numarası BYP-2018-32629. 


\section{Kaynaklar}

Acar D.O., (2007), Türkiye'de açık ocak kömür madenciliği sonrası peyzaj onarım çalışmalarının irdelenmesi, Yüksek Lisans Tezi, Ankara Üniversitesi Fen Bilimleri Enstitüsü, Ankara.

Archibald J.F., (1999), Beneficial impacts of paste tailings on environmental hazard mitigation and engineering performance, International Mining and Environment Congress, Lima, Peru, ss.537-548.

Arol A.İ., (2002), Madencilik atıklarının bertaraf edilme yöntemleri, Madencilikte Çevre Yönetimi Seminer Notları, TMMOB Maden Mühendisleri Odası, Ankara.

Atmaca M., (2001), Afşsin-Elbistan termik santrali açı işletme alanının madencilik sonrası olası alan kullanım alternatiflerinin değerlendirilmesi, Doktora Tezi, Çukurova Üniversitesi, Adana.

Baer R.L., Shermani G.E., Plumb P.D., (1992), Submarine disposal of mill tailings from on-land sources- an overview and bibliography, U.S. Department of the Interior Bureau of Mines, Report No. OFR 89-92, USA.

Bağırsakçı S., (2000), Türkiye'de ve Dünya'da madencilik sektörü, Doktora Tezi, Türkiye ve Orta Doğu Amme İdaresi Enstitüsü Kamu Yönetimi, Ankara.

Berkün M., Önsoy H., (2001), Çayeli Bakır İşletmeleri atıksuları deşarj sistemi için teknik rapor, Karadeniz Teknik Üniversitesi, Trabzon.

ÇBİ, (2013), Derin deniz deşarjı ve macun dolgu uygulamaları teknik kılavuzu, Çayeli Bakır İşletmeleri A.Ş., Yayınlanmamış Rapor, Rize.

Çetiner E.G., Ünver B., Hindistan M.A., (2006), Maden atıklart ile ilgili mevzuat: Avrupa Birliği ve Türkiye, Madencilik, 45(1), 2334.

Dold B., (2014), Submarine tailings disposal (Std)—a review, Minerals, 4, 642-666.

GESAMP (2016), Proceedings of the GESAMP International Workshop on the Impacts of Mine Tailings in the Marine Environment, IMO/FAO/UNESCOIOC/ UNIDO/WMO/IAEA/UN/UNEP/UNDP Joint Group of Experts on the Scientific Aspects of Marine Environmental Protection. Reports and Studies, GESAMP No. 94, 84ss.

Ellis D., Ellis K., (1994), Very deep STD. Marine Pollution Bulletin, 28, 472-476.

İnce S., Engin D., Resen A., (2013), Çayeli Bakır İşletmeleri maden atık çamuru denizaltı depolaması, Bitirme Tezi, İstanbul Üniversitesi Mühendislik Fakültesi Çevre Mühendisliği Bölümü, İstanbul.

İzdar E., (2009), Karadeniz'in hidrografik, biyolojik, fiziksel ve kimyasal özellikleri nedeniyle oluşturduğu tabakalaşmanın anoksik ortamında sülfit içeren atıkların depolanabilirliği, Piri Reis Denizcilik ve Eğitim Vakfı, İzmir.

Karadeniz M., (1996), Cevher zenginleştirme tesis atıkları, çevreye etkileri, önlemler, Nobel Kitabevi, Ankara.

Kayhan H., (2008), Çayeli Bakır Isșletmeleri'ne ait derin deniz deşarjı İle yapılan atıksu boşaltımının deniz ekosistemine etkilerinin belirlenmesi ve yayılımin modellenmesi, Doktora Tezi, KTÜ, Trabzon.

Ramirez-Llodra E., Trannum H. C., Evenset A., Levin L.A., Andersson M., Finne T.E., et al. (2015), Submarine and deep-sea mine tailing placements: a review of current practices, environmental issues, natural analogs and knowledge gaps in Norway and internationally, Marine Pollution Bulletin, 97, 13-35.

Reichelt-Brushett A., (2012), Risk assessment and ecotoxicology. Limitations and recommendations for ocean disposal of mine waste in the Coral Triangle, Oceanography, 25, 40-51.

Shepherd T., Rumengan I., Sahami A., (2018), Post-depositional behaviour of mercury and arsenic in submarine mine tailings deposited in Buyat Bay, North Sulawesi, Indonesia, Marine Environmental Research, 137, 88-97.

Topçu Y., (2012), Liç Atıkları, Atık Depolama Tesisleri ve Koza Uygulamaları, http://www.haliccevre.com/images/2012/342.pdf, [Erişim 20 Temmuz 2019].

Trannum H.C., Gundersen H., Escudero-Oñate C., Johansen J.T., Schaanning M.T., (2018), Effects of submarinemine tailings on macrobenthic community structure and ecosystem processes, Science of the Total Environment, 630, 189-202.

URL-1, (2017), Maden Yönetmeliği, Resmi Gazete, Tarih: 21/09/2017, Say1: 30187, https://www.resmigazete.gov.tr/eskiler/2017/09/ 20170921-1.htm, [Erişim 28 Haziran 2017].

URL-2, (2001), Tailings dams: risk of dangerous occurrences, ICOLD Bulletin 121, http://www.unep.fr/shared/publications/pdf/ 2891-TailingsDams.pdf, [Erişim 16 Nisan 2016].

URL-3, (2010), Hungary's toxic disaster, https://www.aljazeera.com/photo_galleries/europe/2010107204743673559.html, [Erişim 20 Temmuz 2019].

URL-4, (2015), Maden Atıkları Yönetmeliği, Resmi Gazete, Tarih: 15/07/2015, Sayı: 29417, https://www.resmigazete.gov.tr/eskiler/ 2015/07/20150715-3.htm, [Erişim 14 Şubat 2016].

Ünsal I., (2002), Çayeli Bakır İşletmeleri Deniz Deşarjı, Teknik Rapor, İstanbul Teknik Üniversitesi, İstanbul.

Vare L.L., Baker M.C., Howe J.A., Levin L.A., Neira C., Ramirez-Llodra E.Z., Reichelt-Brushett A., Rowden A.A., Shimmield T.M., Simpson S.L., Soto E.H., (2018), Scientific Considerations for the Assessment and Management of Mine Tailings Disposal in the Deep Sea, Frontiers in Marine Science, 5(17), doi: 10.3389/fmars.2018.00017.

Vogt C., (2012), Craig Vogt Inc. Ocean \& Coastal Environmental Consulting. Virginia, USA, http://www.imo.org/en/OurWork/ Environment/LCLP/newandemergingissues/Documents/Mine\%20Tailings\%20Marine\%20and\%20Riverine\%20Disposal\%20Fin al\%20for\%20Web.pdf, [Erişim 10 Mart 2016].

Yüce A.E., (2012), Madenlerde artık uzaklaştırma yöntemleri ve artık yönetimi, Madencilikte Çevre Yönetimi Semineri, TMMOB Maden Mühendisleri Odas1, 12-13 Ocak 2012, Afyon. 